LINGKUNGAN DALAM PEMBELAJARAN BAHASA INDONESIA

ESAI

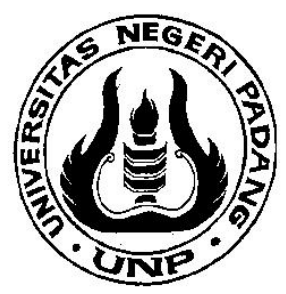

INTI IKHLASANI

NIM 17016088/2017

PROGRAM STUDI PENDIDIKAN BAHASA DAN SASTRA INDONESIA JURUSAN BAHASA DAN SASTRA INDONESIA DAN DAERAH

FAKULTAS BAHASA DAN SENI

UNIVERSITAS NEGERI PADANG

2019 


\section{Lingkungan dalam Pembelajaran Bahasa Indonesia}

Menurut Lai dan Nazarenko (dalam Ramadhan et al, 2019), manusia yang hidup saat ini dihadapkan dengan masalah lingkungan. Umat manusia telah lama dikenal bahwa keberadaannya tergantung pada status lingkungannya. Namun, ketergantungan tersebut justru memunculkan efek negatif terhadap lingkungan. Manusia dapat dikatakan serakah karena hanya mengambil dampak positif yang diberikan lingkungan, tetapi tidak ingin memperbaiki apabila terjadi kerusakan lingkungan. Salah satu efek negatif yang terlihat jelas adalah masih terjadinya pencemaran lingkungan.

Di Indonesia tidak sulit menemukan daerah yang lingkungannya tercemar. Artinya, hampir sebagian besar wilayah di Indonesia lingkungannya tercemar. Bukan hanya lingkungan sosial (umum), bahkan lingkungan pendidikan pun tercemar. Berhubung dengan ketergantungan manusia terhadap lingkungan, sudah sepatutnyalah, lingkungan yang nyaman dan bersih akan menunjang kegiatan pembelajaran yang efektif dan efisien. Akan tetapi, pada kenyataannya, masalah pencemaran lingkungan, misalnya, sampah berserakan di lingkungan kelas merupakan hal lumrah terjadi di dunia pendidikan. Civitas academica yang diharapkan bisa menjaga kelestarian lingkungan supaya tidak tercemar tampaknya gagal. Berdasarkan hasil penelitian penulis, 45,9\% mahasiswa menyatakan sangat setuju bahwa materi lingkungan dalam pembelajaran bahasa Indonesia sangat penting dan $54,1 \%$ mahasiswa menyatakan setuju, tetapi implementasinya jarang dilaksanakan. Pembelajaran bahasa Indonesia erat kaitannya dengan lingkungan $37,8 \%$ sangat setuju, $54,1 \%$ setuju, dan $8,1 \%$ kurang setuju, tetapi peserta didik tampaknya masih menganggap pembelajaran bahasa hanyalah bahasa, tidak ada hubungannya dengan lingkungan. 45,9\% sangat setuju jika dalam pembelajaran bahasa Indonesia pendidik hendaknya menekankan peserta didiknya untuk mencintai dan menjaga lingkungan hidup, sedangkan 51,4\% setuju, dan 2,7\% kurang setuju. Namun, tetap kurang dalam penerapannya. 29,7\% sangat setuju pembelajaran bahasa Indonesia merupakan langkah awal untuk mencegah kerusakan lingkungan, 62,2\% setuju, dan 8,1\% kurang setuju. Pernyataan ini menggambarkan bahwa bahasa adalah pengantar pemahaman peserta didik untuk menerjemahkan kondisi lingkungan sekitarnya. Namun, peserta didik tampaknya masih kurang bisa memahami hal tersebut.

Materi lingkungan dalam pembelajaran bahasa Indonesia sangat dekat dengan kehidupan peserta didik. 37,8\% mahasiswa menyatakan sangat setuju, $56,8 \%$ setuju, dan 5,4\% kurang setuju. Pembelajaran bahasa Indonesia materi lingkungan memberikan efek positif kepada peserta didik sehingga mereka mampu menerapkannya dalam lingkungan. 48,6\% sangat setuju dengan pernyataan ini, 48,6\% setuju, dan 2,7\% kurang setuju. Sementara itu, 37,8\% sangat setuju, 56,8\% setuju pembelajaran bahasa Indonesia bertema lingkungan membuat peserta didik menghargai lingkungannya, sedangkan 5,4\% mahasiswa yang kurang setuju dengan hal tersebut. 35,1\% sangat setuju bahasa Indonesia 
tidak hanya mengkaji hal-hal yang berkaitan dengan kebahasaan, melainkan juga mempelajari tentang lingkungan, 64,9\% menyatakan setuju. Hubungan antara bahasa dan masyarakat merupakan salah satu keterkaitan bahasa dengan lingkungan $35,1 \%$ sangat setuju dan $64,9 \%$ setuju. $32,4 \%$ sangat setuju dengan pernyataan materi lingkungan diperlukan dalam setiap topik pembelajaran bahasa Indonesia. $48,6 \%$ setuju, $16,2 \%$ kurang setuju, dan 2,7\% tidak setuju dengan pernyataan tersebut.

Dalam rangka mengatasi permasalahan kerusakan lingkungan, generasi penerus harus mengambil peran yang besar dimulai dari lingkungan sekitarnya. Pembiasaan yang dimulai dari lingkungan sekitar diharapkan mampu mengurangi efek buruk terhadap lingkungan. Dalam hal ini, peserta didik tidak dibiarkan sendirian. Bimbingan pendidik sangat diperlukan. Nazarenko dan Bergman (dalam Ramadhan et al, 2019), sebagai pengamat, peran penting dalam mengajar pendidikan lingkungan dan menumbuhkan kesadaran siswa tentang lingkungan dimainkan oleh guru. Selanjutnya, Buldur dan Omeroglu (dalam Ramadhan et al, 2019), untuk meningkatkan sikap dan kesadaran siswa terhadap lingkungan diperlukan pendidikan lingkungan. Menurut Hauchild, Poltavthenko dan Stoller (dalam Ramadhan et al, 2019), guru yang berada dalam posisi unik dalam menggalakkan kesadaran lingkungan adalah guru bahasa. Hal ini sesuai dengan hasil penelitian 45,9\% sangat setuju jika dalam pembelajaran bahasa Indonesia pendidik hendaknya menekankan peserta didiknya untuk mencintai dan menjaga lingkungan hidup.

Supaya kerusakan lingkungan tidak terjadi secara berkelanjutan, Ramadhan et al (2019) mengemukakan bahwa penting bagi guru untuk memiliki pengetahuan lingkungan dan memiliki sikap peduli lingkungan. Jika guru tidak memiliki pengetahuan dan sikap, maka belajar bahasa akan menjadi kurang bermakna. Guru harus dapat merancang pembelajaran bahasa dengan mengintegrasikan berbagai topik, salah satunya adalah pendidikan lingkungan. Di samping itu, guru juga dapat menggunakan teks yang terkait dengan lingkungan atau gunakan metode pembelajaran yang sesuai.

Berdasarkan hasil kajian dan penelitian yang dilakukan penulis, dapat disimpulkan bahwasannya setiap orang di lembaga pendidikan memiliki peran penting dalam rangka menjaga lingkungan. Siapa pun itu, tanpa pandang bulu, sudah seharusnya menjaga lingkungan sejak kini. Hal ini dikarenakan, lingkungan yang dijaga sejak dini akan terjaga terus kelestariannya. Selain itu, penanaman kebiasaan menjaga lingkungan juga harus ditanamkan pada diri peserta didik baik melalui pembelajaran langsung atau pun melalui teks-teks yang akan diajarkan. Selanjutnya, pendidikan lingkungan hendaknya dijadikan sebagai topik yang terus-menerus dibahas dalam pembelajaran sebab lingkungan berdampak besar bagi manusia untuk melangsungkan kehidupan. Tulisan ini digunakan sebagai bahan evaluasi bersama untuk penulis, pembaca dan khalayak luas untuk menjaga lingkungan bersama demi terjaganya kelestarian lingkungan. 


\section{Sumber Rujukan}

Bergman, B.G. (2016). Assessing impacts of locally designed environmental education projects on students' environmental attitudes, awareness, and intention to act Environmental Education Reseach 22(4) 480-503.

Buldur, A., and Ömeroglu, E. (2018). An examination of the relationship between pre-school children's and their teacher' attitute and awareness towards the environment Journal of Education and Learning 7(2) 221-9.

Hauchild S., Poltavthenko, E., and Stoller, F. L. (2012) Going green: Menging environmental education and language instruction English Teaching Forum Number 2 2-13.

Lai, C. S. (2018). A study of fifth graders' environmental learning outcomes in Taipei International Journal of Research in Education and Science 4(1) 252-61.

Nazarenko, A. V. and Kolesnik, A. I. (2018). Raising environmental awareness of future teachers International Journal of Instruction 11(3) 63-76.

Ramadhan, S., Sukma, E., \& Indriyani, V. (2019). Environmental education and disaster mitigation through language learning. IOP Conference Series: Earth and Environmental Science, 314. 